\title{
Citizens as Consumers: White Imagined Futures
}

\author{
Oscar J. Mayorga
}

University of California, Los Angeles

\section{Draft Paper from Conference Proceedings}

Race and Capitalism Defined: A Graduate Student Symposium at University of Chicago

February 28, 2020 


\begin{abstract}
This study examines how racial ideologies directly influence perceptions of the economyspecifically, how racial colorblindness ideology, a component of white supremacy ideology, is mediated through market fundamentalism. These findings challenge widely held beliefs that perceptions of the economy are solely driven by economic factors such as family income and employment status. My theoretical approach examines how whiteness and colorblindness shape and distort white consumers' perception of the economy. I develop the framework of white imagined futures. White imagined futures assume a white-owned and white-dominated destiny of wealth and economic success based on an economy that is built to serve white people above all other racial groups. I utilize the American National Election Study due to its measures of racial colorblindness and perception of the economy. I pooled a subsample of the American National Election Study from 2000 to 2016 and conducted an OLS regression and regression-based causal mediation analysis to test how racial and economic ideologies influence perceptions of the economy. The study finds that racial colorblindness serves to stratify present perceptions of the economy and notes how racial colorblindness ideology is also being conveyed through market fundamentalism ideologies. The study also demonstrates that whites' racial ideology has a role in shaping their perceptions of the economy. This evidence supports claims that white supremacy ideology, as defined here, is embedded within markets. Moreover, this study provides evidence that challenges the notions that economic perceptions are solely tied to a person's economic reality (e.g. income, employment status). As a consequence, we can begin to interrogate 'pocketbook' or economic policy talk as a racialized discourse.
\end{abstract}

Keywords: Market fundamentalism, Racial colorblindness ideology, Citizens-Consumer, Regression-based causal mediation analysis, Perceptions of the economy 
Race scholars have outlined the various ways that white supremacist ideology has informed and driven the U.S. state apparatus to build and reify racial disparities through policies affecting political, economic, and social spheres (Jung, Vargas, and Bonilla-Silva 2011). One research thread has focused on how racialized policies and state interventions create structures and outcomes that produce meaningful differences in life chances between white and black people in the United States (Feagin 2000; 2006; Vera and Feagin 2007). ${ }^{1}$ Other race scholars have examined how components of the white supremacy ideology itself are features within capitalism (Cox 1970; Robinson 2000) and western liberal democracy (Mills 1997; 2017). They conclude that exclusion and alienation is central to the political operation of a white supremacist-oriented government.

Both research streams place black people, or people of color generally, as the study subjects. These studies describe the various ways people of color are discriminated against and concludes that the resulting experienced oppression is unjust for any citizen of the polity. The polity is a group of people with a shared political identity within a nation-state or political organization. In other words, race sociology scholarship has argued that a country with the $14^{\text {th }}$ Amendment or constitutional claims of life, liberty, and pursuit of happiness for its citizens, the United States of America has intervened to support racial inequality through passivity or inaction such as not challenging discriminatory practices (i.e. non-enforcement of civil rights laws). The United States government also actively discriminated from supporting the Slave Fugitive Act or using the percent of non-whites and foreigners in a neighborhood as part of the Home Owners'

\footnotetext{
${ }^{1}$ I focus on the white and black racial binary. This does not mean or imply that other non-white racial groups have been unexposed to such factors or their stories are not to be heard. This binary approach is particular to the United States racial doctrine of the $20^{\text {th }}$ century of the one-drop rule and the segregation policy that followed across the United States that has shaped the racial logics of this "empire-nation" (Jung 2015).
} 
Loan Corporation program (i.e. residential redlining segregation). The assumption of inequality and racial capitalism research is that all citizens are entitled to equality from government and society.

Since approximately the 1970s, the citizen to consumer paradigm shift has begun to occurred (Holt 2000). This shift from citizen to consumer has effected the political and legal order of government (Ranchordas 2018). One effect of the shift is around the role of the citizen in relationship to political representatives who are elected to govern. The role of the citizen moved from having "rights and responsibility" to that of entitlement to government services. For example, public policy research has documented how viewing the citizen as a consumer or "taxpayer" has affected issues such as of the role of municipal government (Clarke, Newman, and Westmarland 2007; Rosentraub and Sharp 1981). The consumer-not-citizen paradigm is seen in the rise of the not-in-my-back-yard (NIMBY) phenomenon, especially around zoning and construction of unwanted, but socially necessary services such as subsidize housing, denser housing stock (i.e. non-single family housing) and public transit. This citizens-verses-consumer paradigm helps explain how social responsibility of government has shifted from a public good to one of protection of what is "mine"-a private good. In the demos orientation, society's shift from centering on the citizen to elevating the consumer may be explained by how racialization has functioned in the post-civil rights era.

As key consequence of shifting the demos orientation from citizen to consumer is the transformation of contemporary politics and market-based economies. In seeking office, politicians are concerned about how the tax-payer feels and thinks (Vavreck 2009). In the U.S., powerful political rhetoric helps harness consumer sentiment. Consider Ronald W. Reagan's 1980 presidential debate quip: "Are you better now than four years ago?" Another is William 
Jefferson Clinton's campaign motto "It is the economy, stupid." Vavreck (2009) argues that consumers' perceptions of the economy and how incumbent or challenger candidates message towards them are strong predictors of politicians' electoral success. Here, the consumer is considered the mover of the economy. Thus, political campaigns seek to activate tax-payers with promises of economic growth or promises of their "fair share" of the economy.

What remains unexplored is how racialization, or more broadly white supremacist ideology, is manifested within the demos change from citizen to consumer. As stated previously, political scientists and public policy scholars have focused on the effects of the citizen-consumer shift in terms of regulation, social service programs, and overall governance. The object of their research is to describe the change in practices due to the reorientation from citizen to consumer. On the other hand, sociological race research has not directly considered how the citizen-asconsumer ideology being influenced by the dynamic, contested white supremacy racial order. If we consider the central role of citizens-as-consumers in governance, we will gain insights on how white supremacy ideology functions and informs the demos.

This study delineates how racial colorblindness ideology and whiteness are tools utilized to perpetuate and reify white supremacy in consumer actions. My approach examines how whiteness and colorblindness shape and distort consumers' perception of the economy. I develop the framework of white imagined futures. White imagined futures are a set of beliefs that the "economy" is white-owned, in service to whites, and that whites thus have a destiny to wealth and economic success. In other words, ownership (i.e. capital), wealth, and economic success are based on an economy built to serve whites above all other racial groups. I test how racial and economic ideologies influences perceptions of the economy. The study demonstrates that racial ideology has a role in shaping perceptions of the economy. This evidence supports claims that 
white supremacy ideology, as defined here, is embedded within consumers' imaginations of economic growth. Moreover, this study provides evidence that challenges the notions that economic perceptions are solely tied to a person's economic reality (e.g., income or employment status). As a consequence, we can begin to interrogate 'pocketbook' or economic policy talk as a racialized discourse. I utilize the American National Election Study due to its measures of racial colorblindness and perception of the economy. I pooled a subsample of the American National Election Study from 2000 to 2016 and conducted an OLS regression and regression-based causal mediation analysis to test how racial and economic ideologies influence perceptions of the economy.

\section{White Supremacy Ideology as System}

"This characterization [United States being a white supremacist country] is premised on the notion that a society once expressly organized around white supremacist principles does not cease to be a white supremacist society simply by formally rejecting those principles. The society remains white supremacist in its maintenance of the actual distribution of goods and resources, status, and prestige in which whites establish norms which are ideologically self-reflective." Kimberle Crenshaw (1988) p. 1336.

White supremacy ideology is larger and more pervasive than the normative idea of racial animus held and/or demonstrated by a neo-Nazi or a KKK member. Understanding and conceiving white supremacy as a political system is critical to deconstructing and analyzing white supremacy ideology's structures and functions in the economy. Dylan Rodriguez's (2011) genealogy analysis conceives white supremacy as a socio-historical form. In other words, the process of white supremacy is more than a single ideology or political act. Rodriguez situates white supremacy as encompassing the symbolic (e.g., political or social representation), material (e.g., means of production or distribution of resources), and personal (i.e., how the individual 
person understands reality). Rodriguez's genealogy offers the appropriate scale and scope to conceptualize the dynamic and embedded nature of white supremacy in the U.S. economy. White supremacy is a political economy. That is, white supremacy ideology informs and orders both the political process and economic rules of society (Mills 1997; Omi and Winant 2015). I disagree with critics who doubt the perverseness and the embedded nature of white supremacy ideology in the basic functions of U.S. society. As the epigraph from Crenshaw (1988) states, "society once expressly organized around white supremacist principles does not cease to be a white supremacist society simply by formally rejecting those principles." The consideration of both the political and the economic requires a racial lens, specifically one that centers white supremacy as a political system with a matching economic system that is racialized - racial capitalism. As a result, one who studies the United States' political and economic structures and processes must account for the historical and persistence role of white supremacy.

I am examining two coupled, yet distinct, levels of white supremacy ideology - personal and group level identity. Although I began by considering white supremacy in its broadest scope, it is not feasible to bring all those factors and elements of the broader definition of white supremacy to bear into this study. I focus on connecting both the structural-group (meso level) and personal (micro level) components of white supremacy ideology as understood by the theories of a racialized social system and white racial frames. Eduardo Bonilla Silva's racialized social systems and Joe Feagin's white frames provide the necessary philosophical and theorical scaffolding to understand the mechanism that accurately explains consumer demand for white supremacy. White racial frames details how white people view, interpret, and act on racial events differently than other racial groups, while racialized social system explains how racial ideology 
(e.g., beliefs and attitudes) are structurally built and then are reified by those same structures (e.g., policies and process).

\section{Racialized Social System}

A racialized social system is a social mechanism that creates a white supremacist racial order built and reified by both ideology and institutional racism. Bonilla Silva (2001) argues that the two essential social tools used to maintain the racialized social system are colorblind ideology and practices of new racism (e.g., prima facie race-neutral policies). Colorblind ideology is defined as a set of ideas and perspectives that "binds whites together and glues, shapes and provides the terms of debate [discourse]" (Bonilla-Silva 2001: 189). It stems from ahistorical and decontextualized notions of racial categorization meaning that frame cultural differences as natural, fixed, hereditary, and innate to a people while denying historical and contemporary structural features of discrimination and inequality. ${ }^{2}$ The new racism practices involve a two-move process: first one does not 'see' [acknowledge] race, however, the political, social, and economic practice center race through the lens of race-neutral policies. These raceneutral policies are the contemporary (i.e., post-civil rights) means that maintain the political, social, and economic benefits of white supremacy in the United States.

The shift from blatant Jim Crow and explicitly discriminatory policy to one that was, at prima facie, race neutral became and has remained the means to maintain white supremacy in the United States. Racial colorblind ideology is how whiteness and its benefits are distributed and reified (Bonilla-Silva 2014). I argue that racial colorblindness became the mediating ideology that pays out the wages of whiteness in the $20^{\text {th }}$ century. I will demonstrate that racial

\footnotetext{
2 This definition is built from Bonilla-Silva's four central frames of colorblind racism.
} 
colorblindness became a mediating effect of political and economic beliefs and attitudes for whites from the mid-twentieth century through present day.

\section{Personal, Structural and Ideological Whiteness}

As Bonilla-Silva addresses the ideological and structural components of white supremacy, Feagin's theory of white racial frames examines how people integrate ways of understanding and meaning making that are created and shaped by white supremacy. "Whitecentered racial frame provides an overarching and general destructive worldview, one extending across white division of class, gender, and age" (Feagin 2013: 10). Feagin (2013) argues that white racial frames are comprised of "a beliefs aspect (racial stereotypes and ideologies), integrating cognitive elements (racial interpretations and narratives), visual and auditory elements (racialized images and languages accents), a 'feelings' aspect (racialized emotions), and an inclination to action (to discriminate)" (p.10). That is, Feagin's white racial frames connects a person's individual cognitive and emotional processes to larger racial ideology discourse (i.e., meso level). Moreover, Feagin describes how symbolic and material interactions with a person shapes perception and thus what is considered to be reality. In sum, white racial frames bridges how the individual's racial perception conditions that person's material and symbolic reality. We will see a similar pattern in how contemporary capitalism function in Jens Beckert's theory of imagined futures in an upcoming section. Taking Feagin's and BonillaSilva's frameworks together, I have situated the perception of reality and imagination of the white demos within white supremacy ideology. ${ }^{3}$

\footnotetext{
${ }^{3}$ Although Feagin and Bonilla-Silva are the theoretical foundation for white imagined futures, the origins begin with W.E. B. DuBois's “wages of whiteness". W.E.B. Dubois ([1935] 1998) and David Roediger (2007) respectively conceived and built upon the idea of the wages of whiteness. The wages of whiteness are the mental benefits that poor whites, or whites in general, maintain even or especially when they earn or receive low wages. These mental benefits are realized through holding a superior financial and social prestige when compared to black people of any socioeconomic status. I agree with Dubois and Roediger on the wages of whiteness as being a "psychological wage". Taking the wages of whiteness metaphor further, I am interested in how whites "deposit"
} 


\section{White Demos}

In the United States, whiteness is the 'coin of the realm' and "it has cash value" (Lipsitz 1998, vii). White supremacy's core function is to center and benefit white people through maintaining the concept and related status of whiteness. Whiteness is the means by which material benefit is issued or removed by racial order. Although race is typically tied to the biological feature of skin color or ancestry, whiteness is more than phenotype or parentage. Whiteness is a social category loosely coupled with biology or ancestry, but defined by what Dyer (2015) sets as its assumed definitional normalcy of human existence. In sum, whiteness can, in a narrow scope, be operationalized by a person of a perceptively white phenotype selfidentifying as white. Although a simple construct of whiteness, this assertion provides a broad, but practical, definition of whiteness. The study sample are going to be only white and nonHispanic respondents.

The common thread in understanding the function of white supremacy as political system is threefold. First, meaning making of the demos is coupled with white supremacy in that white supremacy is embedded in creation and interpretation of what it means to be a member of the United States (i.e., white racial frame). Second, the coupling of meaning making and white supremacy is then manifested in the actions and reifications of material and lived experiences through policies, practices, and attitudes across various scopes of society. That is, the consequence of construing interpersonal interactions, policies and events through a white frame is that the material existence reflects that reality (i.e., how we think is how we act). Third, the combination of meaning making and lived experience both creates and maintains an imagined

those wages and how those "earnings" are used by the white demos. This raises critical questions. What social mechanism(s) does white supremacy ideology operate to allow white people to consume whiteness. White supremacy affects people of color. However, because of the nature of power being centered in the white demos in the United States, I am going to focus on white people in this study. 
community for the demos that is embedded in and imbibes white supremacy. In other words, the symbolic, personal, and material of the white demos are encoded with white supremacy. As a consequence, the white demos's imagination of itself is grounded and defined by white supremacy ideology. I am not suggesting a causal order, but one of identifying the components of white supremacy within a socio-historical form. This is an initial framework of a larger and future theoretical paper. This definition of white supremacy is meant to broaden our conception of the role and function of white supremacy as a dynamic, encompassing political system. To be sure, I am not suggesting that white supremacy is determinate of all actions of the white demos. The historical record-those not erased and ignored-demonstrate that resistance to white supremacy has been consistent and long standing. It is through the dialectic between oppression and resistance that we see truth (Hill Collins 2009). From this broadened definition and the understanding it provides, my study focuses on the measurable features of the demos: whiteness and colorblindness.

\section{The Consumer}

Much of the analysis on sociology of consumption has focused on the production and the act of consumption (Zukin and Maguire 2004). Yet, consumption, and thus the consumer, in the $21^{\text {st }}$ century has begun to serve as new sites for examining gender, family, and social class (Zukin and Maguire 2004). One thread of sociology of consumption has been examining the role of cultural tastes and the idea of "cultural ominousness" (Warde 2015). The idea of cultural taste is linked to Bourdieu's idea of cultural capital, fields, and habitus. The focus of cultural tastes or consumption has been on the ways agents have navigated such fields and the mechanisms of establishing and transferring the cultural tastes. However, Zukin and Maguire (2004) and Warde (2015) missed an opportunity to consider how race and racial ideology drive the understanding 
of consumption. Although Zukin and Maguire (2004) did consider the role of ethnicity in consumption, their analysis of ethnicity in the case of Latinos did not consider how ethnic groups are situated in the U.S. racial hierarchy. Their research did not benefit from the later scholarship of Telles and Ortiz (2008) and Itzigsohn (2009) that explained how Latinos, in general, are racialized and subject to racial identity.

Zukin and Maguire's (2004) relevant insight for this study is that consumption, and by extension the consumer, developed a that can express a national or transnational collective identity. The consumer's role is partially "self-managing, enterprising and choosing self," which fits a model of a citizen in a neoliberal society "who shoulder[s] the responsibility for maintaining social order through his or her 'good' choices" (Zukin and Maguire 2004: 182). Zukin and Maguire suggest a casual direction in that consuming culture is shaping collective identity. I suggest that their analysis does not consider how hegemonic ideologies may drive and inform the associated values and meaning attributed to goods and how and who consumed them. We can observe how gender and racial ideologies have shaped the meaning and use of products such as pink toys and goods for girls (Jacobsen 2017) or the cultural appropriations of "black goods" (e.g. music, style) to white people for profit. In sum, Zukin and Maguire bring attention to how their the categorization of the consumer brings forth both the micro and macro in understanding the role of the person and group identity.

Beyond the shift from social responsibility to personal entitlement, what is consumed is also part of the consumer's identity formation. Holt (2000) argues that part of the consumer's identity is the value attached to what is purchased and based on who is able to purchase it. For example, home ownership was a cornerstone of "the American dream". Holt (2000) states that "home ownership became an outward sign of success, of probity (in more objective language, 
creditworthiness), and of having made it into the American middle class" (p. 75). In other words, the "value" of the home is tied not only to physical property, but who does the owing. Thus, the home serves value beyond its physical utility as shelter. Taking into account the racial order of white supremacy ideology in the foundation of this nation and its continued reiterations and reification in society, when black families moved into white neighborhoods, there was strong resistance from their white neighbors that included violence towards those families or white flight (Kruse 2007). As a result, I agree with Holt, that consumer identity is partially defined by social and political order based on the racial exclusion of people of color to the unearned benefits of white people. That is, the consumer, in terms of governance, is focused on their entitlement to receive public goods as private goods. Consumer entitlement is mediated by the U.S. racial order of white supremacy.

\section{Market Fundamentalisms}

Block and Somers offer an ideological analysis of the construction and function of market fundamentalism. One of Block and Somers's strongest contributions is naming the phenomenon in question. Their renaming of neoliberalism as market fundamentalism frames the discussion beyond one of economic policy, and underscores its politically driven orientation. By framing market fundamentalism as quasi-religious, Block and Somers provide an initial hint about why it has so much staying power. Block and Somers are making an ontological argument that the power of market fundamentalism comes from belief in an idea. They point to the belief in market fundamentalism being ungrounded in economic reality or empirical observations, but rather anchored in faith tenants that may fall outside empirical reality. Block and Somers open up a discussion for how ideas have causal powers in making meaning within the world around us. 
Ideas affect the material. Ideational embeddedness is defined by Block and Somers as ideas that have causal powers. I argue that ideational embeddedness is the linchpin of Block and Somers's argument for the power of market fundamentalism. It is through ideational embeddedness that Block and Somers link the world of ideas to the material world. From my own reading, ideational embeddedness provides a mechanism by which these ideas of market fundamentalism (e.g., autonomous self-regulations) can be brought to bear in the material or lived experience of society and government. As stated by Polanyi, the market and its order are derived from and realized through the actions of actors (e.g., government, society, etc.). Block and Somers point to the actors responding to or reifying systems of beliefs. Therefore, if a person subscribes to market fundamentalism, they will act in ways that support those beliefs.

Moral beliefs place values on economic, social positions. By its structured functioning, capitalism has an outcome of poverty. However, "morality" schema places a value on those who are poor or rich. Where the rich are seen as deserving, the poor are considered undeserving. Social naturalism logic presents and frames those who are poor are as the source of their own fate; there is something innate to them or natural that has bestowed such a "terrible" outcome. Morality places the cause of a person's poverty or wealth on themselves and their actions. Block and Somers point to this dynamic as being able to establish the culmination of a social naturalism of the market and the casual power of ideational embeddedness.

The substantive contribution of Block and Somers is their identification of how the market is embedded into society. The market is embedded in society through ideology. Block and Somers argue that the market is a human construction built and shaped by societal ideology. Therefore, market fundamentalist use of social naturalism, ideational embeddedness, and morality of deservedness are the means by which the notion of an autonomous, self-regulating 
market comes into existence and persists in contemporary society. Market fundamentalism is not about policy requirements or positions, such as decreasing food stamp allotment, but a method of re-embedding or intervening to change who benefits from government intervention.

\section{White Imagined Future}

Beckert's imagined futures offers a pathway to connect white supremacy ideology and market functions. Building on Beckert's (2016) imagined futures theory, I have identified the mechanisms by which the relationship between ideas about the markets and the U.S. racial order connect and show how white supremacy is embedded in neoliberalism. As a consequence, I have coined the term white imagined futures. White imagined futures arise from the embeddedness of white supremacy ideology that considers and accounts for the unearned economic benefits of whiteness. White imagined futures assumes a white-owned and white-dominated destiny to wealth and economic success based on an economy built to serve whites above all other racial groups. Thus, whites' perceptions of the economy are decoupled from "economic"4 reality. I argue that the consequence of markets being embedded in white supremacy is that perceptions of those markets or the economy are influenced by racial colorblindness. At the core of racial colorblindness lies indignation or irritation by white people that something perceived to be theirs is taken from them. The unearned benefits of whiteness are perceived as natural and expected while the systematic disadvantage of blackness is framed as a group or cultural failing of black people and by extension, other people of color (Mills 2006, 1994). Ultimately, feelings, perceptions, and actions of colorblindness are part and parcel of white supremacy.

\footnotetext{
4 "Contrary to claims from the sociology of calculations practices, markets cannot be reduced to areas of calculations" (Beckert 2016 p.141). Markets must be understood as narrative that consists of imagined futures of the present in uncertainty.
} 


\section{White Surge: Political, Economic, and Social Life in 2000 - 2016}

I argue that, since the beginning of the $21^{\text {st }}$ century, neoliberal and colorblind ideologies have been hegemonic throughout the U.S. demos. By 2000, three presidential administrations dating from1980 to 2000 (those of Ronald Wilson Reagan, George H.W. Bush, and William Jefferson Clinton) implemented colorblind and neoliberal policies across deregulation of telecommunication, banking, and welfare and criminal reforms, as well as to dismantle unions. At the same time, communities of color were targeted as objects of animus by white communities through popularization of images and descriptions of the so-called welfare queen, cultural poverty deficiencies, black super-predators, and an invasion of 'brown' immigrant people from across the U.S. southern border.

I argue that the distinct neoliberalism and racial colorblindness frameworks engendered and fostered anti-black and anti-brown politics. For example, the Republican Party's primary candidacy of Pat Buchanan in 2000 was a clear national sign of the mix between neoliberal and racial animus politics. Buchanan was a precursor of the racial nativism expressed by presidential candidates in 2016. Buchanan's candidacy was denounced by his party's elites, yet it resonated with the Republican Party polity. Racialized nativism is also exhibited by the success of similar white supremacist candidates such as Steven King (R) of Iowa $4^{\text {th }}$ District and Peter King of $2^{\text {nd }}$ District of New York. In 2004, the passage of anti-immigration legislation and anti-gay bills brought George W. Bush his reelection. Although it might be said that Obama's election was an exception because he was the United States' first mixed-raced and visibly black president, I argue, along with other scholars, that Obama's paternalistic notions of race appeared to use respectability politics and tropes to admonish black families. Simultaneous with Obama's administration, was the blatantly racist movement of the Tea Party (approximately between 2009 
and 2012). Moreover, Obama was known to those aware of his administration's record-setting number of deportations as the "deporter-in-chief." Next, the $45^{\text {th }}$ U.S. President kicked off his campaign by labeling Mexican people as rapists who were illegally crossing the border in droves. In sum, the political discourse of this period (2000 to 2016) had clear racial frames that infused neoliberal economic policies.

\section{Hypothesis}

I argue that white supremacy is consumed by the white demos. To prove this claim, I tested three hypotheses that build upon each other.

Hypothesis 1: Perceptions of the economy are directly influenced by ideology. Perception of the economy is not singularly driven by employment status, family income, and years of education.

The first hypothesis tested if the perception of the economy is first influenced by ideology. Predominate understanding presents the economy as based on the material experience of individuals. This hypothesis tests the Becker's demand-side theory of capitalism. If a person's experience of the economy is based solely on their material reality, the null hypothesis is that there is no relationship between ideological measures (e.g., colorblindness, market fundamentalism, etc.) on their perception of the economy. Thus, the expectation would assert that only levels of education, employment status, and family income affect perceptions of the economy. I hypothesize that there will be a statistically significant effect between ideological measures and perception of the economy.

Hypothesis 2: Perceptions of the economy are directly influenced and mediated by racial colorblindness.

The next hypothesis tests whether the claim that white supremacy, as described in this study, is embedded in the imagination of the white demos and/or if there is a white imagined future. Racial colorblindness ideology is a covariate in the model. I tested if there is a direct effect of 
racial colorblindness on perception of the economy. I hypothesized that there is a direct effect between racial colorblind ideology and perception of the economy.

Hypothesis 3: Market fundamentalism is an ideological tool of racial colorblindness. Lastly, I tested if racial colorblindness is mediated in market fundamentalism. Using the regression-based causal mediation method, I examined if the dominant ideology in the political sphere - market fundamentalism (also known as neoliberalism) - furthers racial colorblindness. I hypothesize that market fundamentalism is mediated by racial colorblindness.

\section{Methods}

\section{Data and Sample}

The American National Election Study is a collaboration between Stanford University and University of Michigan to collect public opinion, voting, and civic participation data (The American National Election Studies 2012). The study contains an ideal dataset because it has collected nationally representative data on various survey items, including attitudes of racial resentment, the economy, and federal budget spending priorities, as well as questions about ideological preferences (e.g., neoliberalism and political orientation). The American National Election Study is administered during presidential election years ${ }^{5}$.

I use the American National Election Study dataset because it provides the best means to examine respondents' perceptions of the economy and levels of racial colorblindness. Political campaigns prime the demos to think about their financial circumstances (Vavreck 2009). Vavreck points to how the centrality of the nation's economy in elections and political campaigns' framing and discussion of the economy can lead to electoral success or failure. However, discussions on the economy are not the only substantive issues discussed in elections.

\footnotetext{
${ }^{5}$ The ANES was also administered during mid-term elections. The practice ended in 2002.
} 
Other studies have pointed to the importance and role of racial politics and issues (Haney-López 2014). Building upon the insights of Haney-Lopez and Vavreck, use of the American National Election Study provides the context of elections where both economy and race are at the forefront since ANES has measures of both racial colorblindness as well as perceptions of the nation's economy. I pooled a subsample of the American National Election Study from 2000 to 2016. Sample weights were necessary to obtain accurate estimates and standard errors (DeBell 2010). From the sample weights, I also created bootstrapping weights. The total sample size is $\sim 40,756.921$ (weighted). Whites comprised the focus subpopulation for my study at a total of $\sim 6,469.269$ (weighted).

\section{Dependent Variable}

Perceptions of the Economy. Due to the temporal nature of the phenomena, there are two measures of the dependent variable. The first measure is the respondents' perception of the present economy compared to that of the prior year. The item stem is: "U.S. economy better or worse than 1 year ago?" The present measures the interpretation of their current circumstance compared to their perception of their circumstance of one year before. The other survey item future perceptions of the economy - has the stem: "U.S. economy better or worse 1 year from now?" Future perception of the economy asks the respondent to speculate about the future of the economy. The scale for both measures is “Don't know/Uncertain (0), Worse (1), Same (2) and Better (0)." I argue that this item informs how ideology shapes people's perceptions about the economy because white imagined futures is based upon perceptions rather than real economic metrics. The questions asks respondents to reflect upon their present interpretation as well as to speculate about the future. This exercise of interpretation and speculation based on the respondents' experiences is a key attribute of the dependent variable. 
Mediator

Colorblindness. Colorblindness was constructed using confirmatory factor analysis; the details of the factor analysis can be found in the appendix. The racial colorblindness factor is constructed from items such as "Past slavery make more difficult for blacks," "Blacks gotten less than they deserve over the past few years," "Blacks must try harder to succeed," and "Blacks should not have special favors to succeed." These are Likert items with a five-point scale (Strongly Agree, Somewhat Agree, Neither Agree/Disagree, Somewhat disagrees, Strongly Disagree). I also included an "Aid to blacks" scale which ask respondents to rate if blacks should receive government assistance. The seven-point scale range was from "Blacks should help themselves" to "Government should help Blacks." These items capture how black people have been portrayed as undeserving while white people are portrayed as deserving.

\section{Covariates Variables}

Family Income. There are two standard economic drivers in stratification literature: income and years of education (Blau and Duncan 1967; DiPrete 2002; Spilerman 1977; Treiman and Ganzeboom 2000). Both are demonstrated indicators that drive economic mobility (Hollister 2011; Hout 2012). In the study, the family income variable is a respondent's self-reported family income that has been placed in a group percentile.

Years of Education. The number of years of education was recoded as the highest year for any category. For instance, 11 was given to a respondent holding less than a high school credential, while 12 was given for a high school credential.

Conservative Ideology. Pundits and social scientists alike have made a point to discuss how political discourses have become polarized across parties, if not ideologies (i.e. conservative and liberal). Moreover, scholars have pointed to the centrality of political ideology as a way to make meaning of other social issues (Boutyline and Vaisey 2016). The conservative ideology is a self- 
reporting item comprised of a seven-point scale scoring from "extremely liberal" to "extremely conservative." The mid-point or "4" is labeled "moderate or middle of the road."

Market Fundamentalism. In this study, market fundamentalism is a factor variable. The factor was created from survey items that measured respondents" preferences towards the role of free market policy orientation in handling the economy and social problems. (See Appendix for CFA analysis). A key component within the market fundamentalism framework is the language used to develop the factor. Items within the factor align with the verbiage employed by Milton Freidman to discuss and argue for neoliberal policies (Harvey 2005). The market fundamentalism approach continues to be viewed as the best solution to address social problems, how the government should be oriented, and how the economy should be handled.

Less Federal Spending. The less federal spending factor variable operationalizes one distinct feature of libertarian perspectives, which is less government spending on social programs. The item stem is asking respondents if they want to increase, decrease, or maintain the (then current) level of funding across a variety of social programs such as social security, welfare, public education, etc.

Gender. The ANES has a binary sex question and I have coded as dichotomous. Men are the reference group.

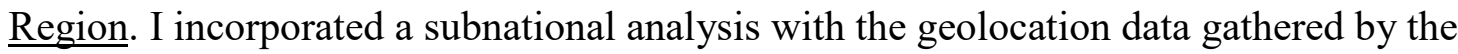
ANES. In the OLS regression analysis, I divided regions by Northeast, Midwest, South, and West. The regression-based mediation analysis requires that all continuous variables be dichotomous. Thus, I recoded the variable to South/Non-South, with South being the reference group. 
Economic Vulnerability. Economic vulnerability measures the overall employment security of respondents. A respondent's employment status can place their income and years of education in context. The composite variable is constructed by two items. The first item asked the respondents if they had been laid off in the last six (6) months. The second item asked respondents if their hours were cut or if they had a reduction in pay. The economic vulnerability categories were: 3 "laid off," 2 "marginal part-time,",1 "reduced hours," 0 "fully employed." Marginal part-time is defined as a respondent answering yes to both items. In other words, they were laid off and they had their hours cut or received a reduction in pay. It is important to note that in the reduce hour question, the option for not currently working is different from reduced hours. I interpreted that the respondent who selected the former item had lost full-time employment, but was employed in some part-time capacity. The reduced hours category identified when a respondent answered 'yes' to being laid off and answered 'no' to the reduced hours question. I made the interpretation that the respondent who selected this option was working in some part-time capacity, however, their position(s) may have been more stable because hours were not reduced. In the mediation analysis, I created a dichotomous categorical variable where the employed are coded as zero (0) and vulnerable are coded as one (1).

Time. My sample spans five presidential elections that occurred in 2000, 2004, 2008, 2012 and 2016. In my OLS regression analysis, the 2016 respondents serve as the reference group. In the mediation analysis, I created a dichotomous variable that is the pooled 2000 - 2016 elections compared to all other elections.

\section{Plan of Analysis}

I used a bootstrap OLS regression and regression-based causal mediation analysis. The factor analysis, although important, did not contribute to the discussion of the study. I have placed the details of the confirmatory factor analysis in Appendix A. Bootstrapping the survey weights built 
a more robust confidence interval by reducing the standard error terms for both the OLS regression and mediation analysis (MacKinnon 2008). The bootstrapping weights were derived from the sample survey weights and all analysis consisted of 1,000 iterations.

Mediation analysis is not a new method, however, the continual iteration has sought to improve the casual inferences that can be drawn (MacKinnon 2008; VanderWeele 2015; Hayes 2018). Regression-based mediation analysis is the latest version to improve research's ability to make causal claims. Vanderweele's (2015) regression-based mediation analysis uses a counterfactual framework and analytical formulation to justify making causal claims. Without delving into the technical specificity of the method (See Vanderweele 2015 chapters 2 and 3), there are three key differences that Vanderweele provides than previous mediation analysis. First, four assumptions ground the mediation analysis into the counterfactual's causal frameworks posited by Pearl (2010). Vanderweele (2015) argues that if these assumptions are not met, one cannot make causal claims. My analysis meets all the assumptions.

The second and third differences concern how the mediation analysis is constructed. Vanderweele inserts an interaction term between the exposure variable (A) and the mediation variable $(\mathrm{M})-\mathrm{A} * \mathrm{M}$. Moreover, the mediation effect is determined by computing the difference between different exposure levels at a and $\mathrm{a}^{*}$. In other words, the exposure variable must be assigned a value and an alternative value. The mediation effect is determined through this difference of exposure levels. The fourth difference is bootstrapping in order to obtain robust confidence intervals (VanderWeele 2015; MacKinnon 2008). In Stata, the program -paramedwas created using Vanderweele technical formulation. Using the -paramed-programming syntax, I created my own bootstraps using the ANES survey weights to conduct 1,000 iteration bootstrapping. I computed the Natural Direct and Indirect effects. 


\section{Findings}

Key Findings

I found that an increase in racial colorblindness also increases the respondents' positive perception of the economy for both the present and future. Because the interaction term is statistically significant for both models (Table 1), the role of market fundamentalism must be accounted for. In Figure 1, the y axis is perception of the present economy where 3 "is going to do better" and 1 "doing worse." The $\mathrm{x}$ axis is level colorblindness; the value of 1 is the mean of colorblindness measure. What we observe is that respondents with lower levels of colorblindness and a higher level of market fundamentalism have a more positive perception of the present economy. As respondents' level of colorblindness increases, while the market fundamentalism level remains constant, we see an inversion of the relationship between colorblindness and market fundamentalism. Respondents with higher colorblindness and market fundamentalism levels have a worse perception of the present economy compared to those with lower levels of market fundamentalism. While respondents with lower levels racial colorblindness had perception of the economy that are close together regardless of level of market fundamentalism (i.e. their confidence intervals are overlapping). In other words, racial colorblindness servers to stratify present perceptions of the economy. The future economic perception follows a similar pattern to the perception of present economic future (Figure 2). In addition to OLS, the causal mediation analysis findings show that 27 percent of market fundamentalism is mediated by colorblindness for present perception of the economy. The mediation of racial colorblindness was at three percent for future perception of the economy. 
Other Findings

The model had several covariates to control for effects such as income, years of education, and region, among others. The following section provides a general description of those covariates' effects. It is important to note that the covariates do not substantially impact the main effect.

Present Perception of the Economy

In the model, we account for several other covariates (see Table 1). Level of conservatism is not statistically significant. Respondents who held beliefs that the government should have less federal spending had a more positive present perception of the economy $(\mathrm{p}<.001)$. While for every increase of year(s) of education (Coef. $=.02, \mathrm{p}<.001)$, there is one unit increase in the present perception of the economy. There is a small percentage increase in family income percentage to increase in perception of the economy. Men perceive the economy more favorably than women by $.06(\mathrm{p}<.001)$. The South perceived the economy better than the other regions in the country (e.g. Northeast, Midwest, and West). The unemployed perceived the economy more favorably than those who experienced reduced hours and marginal employment; while the employed had a more favorable perception of the economy than the unemployed. Respondents in the 2000, 2004, and 2012 editions of the study had better perception of the economy than those in 2016. While respondents in 2016 perceived the economy more favorably than those in 2008.

\section{Future Perception of the Economy}

In the model, we account for several other covariates (see Table 1). Level of conservatism and family income percentile are not statistically significant. Respondents who held beliefs that the government should have less federal spending had a more positive present perception of the economy $(\mathrm{p}<.001)$. Yet, for every increase of year(s) of education $($ Coef $=.01, \mathrm{p}<.001)$, there is one unit increase in the present perception of the economy. Men perceive the economy better than women by $.07(\mathrm{p}<.001)$. The South perceived the economy more favorably than the other regions in the country (e.g. New England, Midwest and West). The unemployed perceived the 
economy better than those who received reduced hours; while the employed and marginal employment had a more favorable perception of the economy than the unemployed. Respondents in the 2000, 2004, and 2012 editions of the study had better perception of the economy than those in 2016. Respondents in 2016 perceived the economy better than those surveyed in 2008.

\section{Discussion}

Hypothesis 1: Perceptions of the economy are directly influenced by ideology. Perception of the economy is not singularly driven by employment status, family income, and years of education.

Accounting for income, years of education, political ideology, and employment status, I found that a respondent's level of colorblindness and market fundamentalism directly influenced their perception of the economy. This evidence supports the theoretical claims of Jen Beckert and Friedrich A. Hayek that the economy can be understood by persons as one of expectations and narrative. To be clear, I am making a distinction between the millions, if not billions, of individual transactions across persons, companies, and nations, and between how any one person understands and can comprehend all of these transactions and their meaning. Still, this is direct evidence that the standard or accepted operational understanding of the economy or market must take ideology into account.

Hypothesis 2: The ideology is embedded in white supremacy.

Establishing that market perceptions are ideologically driven, we can consider the nature of said ideology. The second hypothesis tested if markets as ideological constructs are embedded in white supremacy. Karl Polanyi (2001) argues that markets are embedded in society, meaning that markets are informed and created by society and not divinely ordained social mechanisms that order economy production and demand. My findings show that the social order given to the "market" is influenced and informed by white supremacy. The direct effect of colorblindness on 
perceptions of the economy is clear - the more colorblindness, the better respondents perceived the economy to be. To reiterate, the measure of racial colorblindness does not ignore the country's racist history and its effects on the economic lives of African-Americans or those perceived by whites to be black people. Moreover, the measure also picks up attitudes that African-Americans and other people who are perceived as non-white should not receive "additional" benefits. These sentiments of deserving and undeserving are at the core of market fundamentalism ideology (Block and Somers 2014).

Of particular interest among the findings is the effect of colorblindness and market fundamentalism. With an increase of both colorblindness and market fundamentalism, the selected answers revealed a decrease in perception of the economy for white, non-Hispanic respondents. Whites' lower perception of the economy stemmed from the interaction between racial colorblindness's core component of resentment and the underlying deserving/underserving logic of market fundamentalism (Block and Somers 2014). I argue that market fundamentalism heightens the resentment/underserving nature of the racial colorblindness ideology.

The findings help us observe both functions of white supremacy - the unearned benefit for white people and penalty for people of color (Mills 1994; 1997). The perception of the economy is tied to notions of who is receiving benefits. Someone who is racially colorblind, and an adherent of low market fundamentalism, could be described or identify politically as a Democrat, while someone with higher adherence to market fundamentalism and colorblindness could be described as a Republican.

\section{Hypothesis 3: Market fundamentalism is an ideological tool of white supremacy.}

The findings offer additional insight into the role of market fundamentalism. The effect of market fundamentalism is mediated 27 percent by racial colorblindness for present perceptions 
of the economy and three percent for future perceptions of the economy at exposure levels a and $a^{*}$. These findings reveal a clear connection between white supremacy and market fundamentalism. It appears that the market fundamentalism for the present perception of the economy is more affected by the mediating effects of colorblindness than future perceptions of the economy. Market fundamentalism's role in the future perception of the economy may lie outside a strong racial role. Block and Somers (2014) have described market fundamentalism as painting the narrative of the deserving. Ultimately, racial colorblindness and market fundamentalism reify the white supremacist ideology that people of color are absent in the white narrative of America's economic growth and deservingness.

\section{Racial Colorblindness as White Imagined Futures}

My study offers two critical takeaway points. First, white imagined futures offers an explanation of how whites decouple economic perceptions from their economic reality. The decoupling of a white person's economic reality from economic perceptions is a function of: 1) the nature of economic perceptions being grounded in desire, credit, and positive economic narrative, and 2) economic perceptions being embedded in white supremacy. Therefore, I argue that white economic decline rhetoric can be partly attributed to white people experiencing a decline in returns of their symbolic value of whiteness.

This paper's second implication is the need to reconsider our communal notions of racial progress when recognizing that white people's consumption of white supremacy distorts their perception of reality. During the Obama presidency, there was much rhetoric about beginning a post-racial society (Kendi 2017). Popular discourse used the marker of Obama's election and the increase of non-white voices in politics along with economic leaders as signifiers of an era of successful racial progress (Coates 2017). I found in the study that with an increased perception of 
non-white success, there is a corresponding increase in whites' perception that the economy is worsening.

There are ramifications for society as a whole if success and upward mobility by people of color is and will continue to be contested. I argue that the presence and breadth of colorblindness's effect and the social mechanism of racialized perceptions of the economy challenge notions of "natural" racial progress within the United States. The idea of racial progress has served as a rhetorical tool to justify and condone neoliberal economic policies. We now have evidence that suggests that racial colorblindness is also being "distributed" through market fundamentalism discourse and policies. Key in these findings is that both political parties within the United States have policies grounded in market fundamentalist principles (e.g. Obamacare and Bill Clinton's welfare reform).

Whites' decoupling of economic perceptions from economic realities is a consequence of white imagined futures. Race scholars and activists can begin to articulate to the electorate how economic discourse is racialized. Thus, the next step is an exploration of how to disrupt white supremacy's symbolic value and attempt to embed the values of equity and solidarity into the white imagination.

Ultimately, the work for racial equity may not be found within the well-trodden paths of political parties. Like the Memphis Sanitation Workers Strike in 1968 and the Black Lives Matter movement of today, the fight for equity has a discourse that falls outside the established narrative and palatable notions of racial progress. In other words, the means of equity may be impossible to construct with the current social understandings and political tools. As a result, there must be a reframing of how debates about economic policies occur. All economic policies grounded in neoliberalism and conservative ideologies should be considered suspect. 


\section{References}

Clarke, John, Janet Newman, and Louise Westmarland. 2007. "Creating Citizen-Consumers? Public Service Reform and (Un)Willing Selves.” In On Willing Selves, edited by Sabine Maasen and Barbara Sutter, 125-45. London: Palgrave Macmillan UK. https://doi.org/10.1057/9780230592087 6.

Cox, Oliver Cromwell. 1970. Caste, Class and Race: A Study in Social Dynamics. 4th pr. New York, NY: Modern Reader Paperbacks.

Crenshaw, Kimberle Williams. 1988. "Race, Reform, and Retrenchment: Transformation and Legitimation in Antidiscrimination Law." Harvard Law Review 101 (7): 1331-87.

Du Bois, William Edward Burghardt. 1935. Black Reconstruction in America: [ 1860 - 1880]. 1. ed. New York, NY: The Free Press.

Feagin, Joe R. 2000. Racist America: Roots, Current Realities, and Future Reparations. New York: Routledge.

—. 2006. Systemic Racism: A Theory of Oppression. New York: Routledge. . 2013. The White Racial Frame: Centuries of Racial Framing and Counter-Framing. 2nd ed. New York: Routledge.

Haney-López, Ian. 2014. Dog Whistle Politics: How Coded Racial Appeals Have Reinvented Racism and Wrecked the Middle Class. Oxford: Oxford Univ. Press.

Hayes, Andrew F. 2018. Introduction to Mediation, Moderation, and Conditional Process Analysis: A Regression-Based Approach. Second edition. Methodology in the Social Sciences. New York: Guilford Press.

Hill Collins, Patricia. 2009. Black Feminist Thought: Knowledge, Consciousness, and the Politics of Empowerment. 2nd ed. Routledge Classics. New York: Routledge.

Holt, Thomas C. 2000. The Problem of Race in the Twenty-First Century. The Nathan I. Huggins Lectures. Cambridge, MA: Harvard University Press.

Itzigsohn, José. 2009. Encountering American Faultlines: Race, Class, and the Dominican Experience in Providence. New York, N.Y.: Russell Sage foundation.

Jacobsen, Kenneth A. 2017. "Rolling Back the Pink Tax: Dim Prospects for Eliminating GenderBased Price Discrimination in the Sale of Consumer Goods and Services." California Western Law Review, no. 2 (2018): 241-66.

Jung, Moon-Kie, João H. Costa Vargas, and Eduardo Bonilla-Silva, eds. 2011. State of White Supremacy: Racism, Governance, and the United States. Stanford, California: Stanford University Press.

Karl Polanyi. 2001. The Great Transformation: The Political and Economic Origins of Our Time. Boston, MA: Beacon Press.

Kruse, Kevin Michael. 2007. White Flight: Atlanta and the Making of Modern Conservatism.

Lipsitz, George. 1998. The Possessive Investment in Whiteness: How White People Profit from Identity Politics. Philadelphia: Temple University Press.

MacKinnon, David Peter. 2008. Introduction to Statistical Mediation Analysis. Multivariate Applications. New York: Lawrence Erlbaum Associates.

Mills, Charles W. 1994. "Revisionist Ontologies: Theorizing White Supremacy." Social and Economic Studies 43 (3): 471. . 1997. The Racial Contract. Ithaca: Cornell University Press. . 2017. Black Rights/White Wrongs: The Critique of Racial Liberalism. Transgressing Boundaries. New York, NY: Oxford University Press. 
Omi, Michael, and Howard Winant. 2015. Racial Formation in the United States. Third edition. New York: Routledge/Taylor \& Francis Group.

Pearl, Judea. 2010. “The Foundations of Causal Inference.” Sociological Methodology 40 (1): $75-149$.

Ranchordas, Sofia. 2018. "Citizens as Consumers in the Data Economy: The Case of Smart Cities." SSRN Electronic Journal. https://doi.org/10.2139/ssrn.3216389.

Robinson, Cedric J. 2000. Black Marxism: The Making of the Black Radical Tradition. Chapel Hill, N.C: University of North Carolina Press.

Roediger, David R. 2007. The Wages of Whiteness: Race and the Making of the American Working Class. Rev. ed. Haymarket Series. London; New York: Verso.

Rosentraub, Mark S, and Elaine B Sharp. 1981. "CONSUMERS AS PRODUCERS OF SOCIAL SERVICES: COPRODUCTION AND THE LEVEL OF SOCIAL SERVICES," 39.

Telles, Edward Eric, and Vilma Ortiz. 2008. Generations of Exclusion: Mexican Americans, Assimilation, and Race. New York: Russell Sage Foundation.

VanderWeele, Tyler J. 2015. Explanation in Causal Inference: Methods for Mediation and Interaction. New York: Oxford University Press.

Vavreck, Lynn. 2009. The Message Matters: The Economy and Presidential Campaigns. Princeton, N.J: Princeton University Press.

Vera, Hernan, and Joe R. Feagin, eds. 2007. Handbook of the Sociology of Racial and Ethnic Relations. Handbooks of Sociology and Social Research. New York: Springer.

Warde, Alan. 2015. "The Sociology of Consumption: Its Recent Development." Annual Review of Sociology 41 (1): 117-34. https://doi.org/10.1146/annurev-soc-071913-043208.

Zukin, Sharon, and Jennifer Smith Maguire. 2004. "Consumers and Consumption." Annual Review of Sociology 30 (1): 173-97.

https://doi.org/10.1146/annurev.soc.30.012703.110553. 
Table 1. OLS Regression Model for Perception of the Economy

\begin{tabular}{|c|c|c|c|c|}
\hline \multirow[t]{3}{*}{ Variables } & \multicolumn{2}{|c|}{ Present } & \multicolumn{2}{|c|}{ Future } \\
\hline & & Standarc & & Standard \\
\hline & Coef. & Error & Coef. & Error \\
\hline Colorblindness & $2.19 * * *$ & $(0.21)$ & $0.91 * * *$ & $(0.23)$ \\
\hline Marker Fundamentalism & $1.62 * * *$ & $(0.22)$ & $0.64 * *$ & $(0.25)$ \\
\hline Colorblindness by Market & & & & \\
\hline Fundamentalism Interaction & $-2.50 * * *$ & $(0.21)$ & $-0.94 * * *$ & $(0.23)$ \\
\hline Less Federal Spending & 0.07 & $(0.07)$ & $-0.52 * * *$ & $(0.06)$ \\
\hline Conservatism & -0.01 & $(0.00)$ & -0.01 & $(0.00)$ \\
\hline Income Group Percentage & $0.00 * * *$ & $(0.00)$ & 0.00 & $(0.00)$ \\
\hline Years of Education & $0.02 * * *$ & $(0.00)$ & $0.01 * * *$ & $(0.00)$ \\
\hline \multicolumn{5}{|l|}{ Region $^{\wedge}$} \\
\hline New England & $-0.16^{* * *}$ & $(0.02)$ & $-0.10 * * *$ & $(0.01)$ \\
\hline Midwest & $-0.08 * * *$ & $(0.02)$ & $-0.05 * * *$ & $(0.01)$ \\
\hline West & $-0.07 * * *$ & $(0.02)$ & 0.02 & $(0.01)$ \\
\hline Women & $-0.06 * * *$ & $(0.01)$ & $-0.07 * * *$ & $(0.01)$ \\
\hline \multicolumn{5}{|l|}{ Economic Vulnerability^^ } \\
\hline Employed & $0.25 * * *$ & $(0.01)$ & $0.08 * * *$ & $(0.01)$ \\
\hline Reduced Hours & $-0.23 * * *$ & $(0.02)$ & $-0.16 * * *$ & $(0.02)$ \\
\hline Marginal Employment & $-0.17 * * *$ & $(0.02)$ & $0.13 * * *$ & $(0.02)$ \\
\hline \multicolumn{5}{|l|}{ Years $^{\wedge \wedge \wedge}$} \\
\hline 2000 & $0.18 * * *$ & $(0.01)$ & $0.11 * * *$ & $(0.02)$ \\
\hline 2004 & $0.15^{* * *}$ & $(0.02)$ & $0.05 *$ & $(0.02)$ \\
\hline 2008 & $-0.18 * * *$ & $(0.02)$ & $-0.11 * * *$ & $(0.02)$ \\
\hline 2012 & $0.06^{* * *}$ & $(0.02)$ & $0.03 * *$ & $(0.01)$ \\
\hline Constant & 0.25 & $(0.22)$ & $2.03 * * *$ & $(0.26)$ \\
\hline Observations & 38,352 & & 38,357 & \\
\hline R-squared & 0.10 & & 0.03 & \\
\hline
\end{tabular}

$* * * \mathrm{p}<0.01, * * \mathrm{p}<0.05, * \mathrm{p}<0.1$

Whites Only (White and Non-Hispanic)

1000 Replication from Bootstrapping

$\wedge$ Reference Group: South

$\wedge \wedge$ Reference Group: Unemployed

$\wedge^{\wedge \wedge}$ Reference Group: 2016 
Figure 1. Main Effects of Perception of the Present Economy

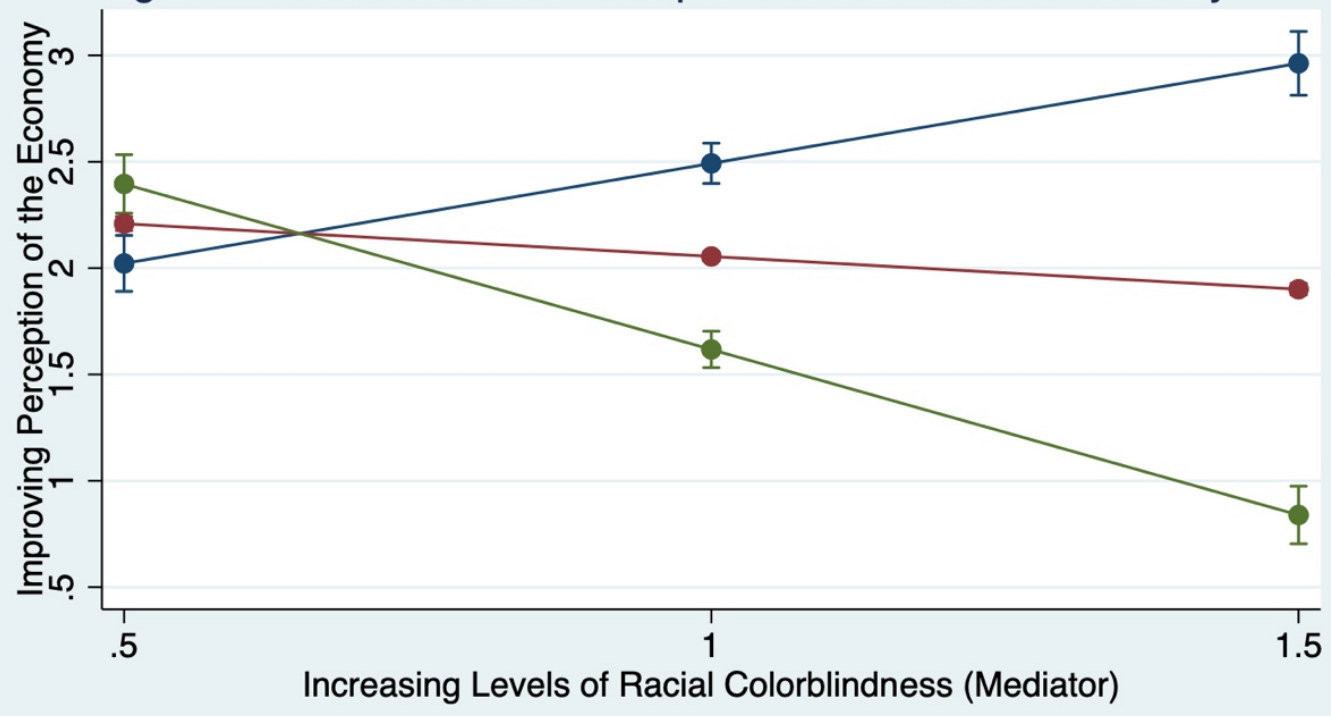

$\longrightarrow$ Market Fundamentalism at .5 $\longrightarrow$ Market Fundamentalism at 1

- Market Fundamentalism at 1.5

Market Fundamentalism is the Exposure Variable

Figure 2. Main Effects of Perception of the Future Economy

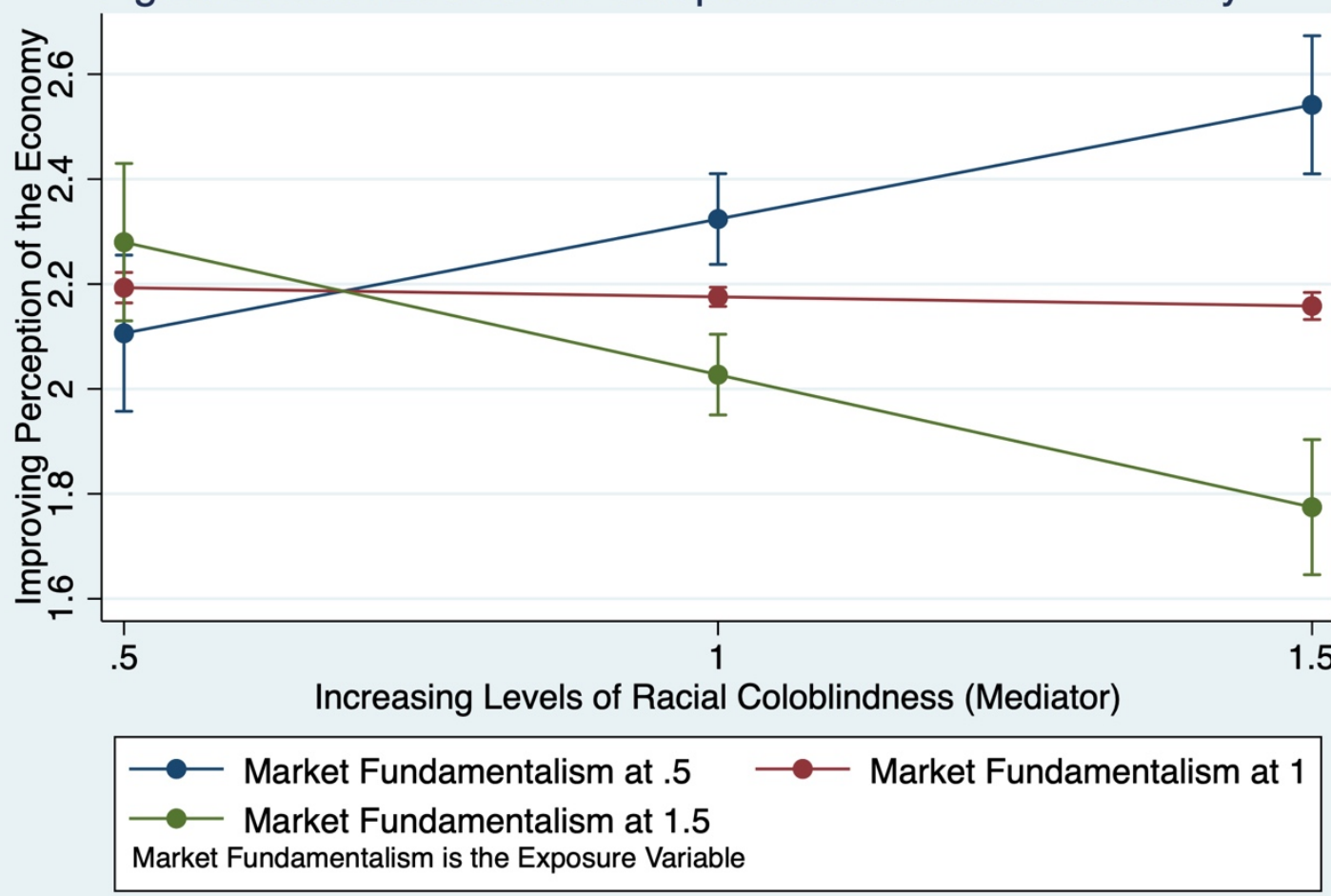

